\title{
Historical Origin and Mission of Ho Chi Minh's Philosophy
}

\author{
Dr. Duong, Nguyen Ba \\ Assoc. Professor \\ Institute for Military Social Sciences and Humanities, Hanoi, Viet Nam
}

\begin{abstract}
The article analyzes and comments that the philosophical ideology is an important part of Ho Chi Minh's ideology, reflects the Ho Chi Minh's worldview, outlook on life and scientific methodology and revolutionary lines on fundamental issues of the fighting for national liberation, social liberation and human liberation, the result of the inheritance, the application and the creative development of the quintessence of the mind and culture of the nation and mankind to the specific conditions of Vietnam. The article discusses the origin of the formation and development of Ho Chi Minh philosophical ideology on the basis of analyzing, indicating objective conditions and subjective factors; emphasizing the relationship between the philosophical ideology of the Vietnamese people and the culture of the East and the West; Marxist-Leninist philosophy and the practical origin, personality of Ho Chi Minh; affirming the role of each factor in forming the independent, creative, dialectical philosophical thinking style of Ho Chi Minh's philosophy. Thereby, it points out the nature, stature, value, meaning and uniqueness of Ho Chi Minh's philosophical ideology, at the same time, asserts that Ho Chi Minh is not only a leader of the Vietnamese people, a world cultural celebrity, but also a typical philosopher of the Vietnamese nation in the modern time.

Keywords: Ho Chi Minh, Ho Chi Minh philosophy, ideology, Vietnamese national culture, Confucianism, Buddhism, Taoism; Eastern and Western philosophical ideology; worldview, outlook on life, dialectical materialistic methodology
\end{abstract}

DOI: $10.7176 /$ RHSS/9-2-01

\section{Introduction}

Ho Chi Minh (1890 - 1969), is the Vietnamese politician, revolutionist; the State President, the founder of the Communist Party of Vietnam; one of the founders and leaders of the struggle for national independence, territorial integrity of Vietnam in the twentieth century. Ho Chi Minh is the author of the Declaration of Independence, founding the Democratic Republic of Vietnam on September $2^{\text {nd }}, 1945$.

Ho Chi Minh's ideology is a comprehensive, deep viewpoint system of the fundamental issues of the Vietnamese revolution, the result of the application and creative development of the quintessence of the Eastern, the West and mankind ideology and culture. In which, the ideology of national liberation, social liberation, human liberation, the combination of national strength with the power of the times; the strength of the people, the great national unity block, etc., of which the core content is that the philosophical ideology occupies a particularly important position. Studying the nature and origin of the formation and development as well as affirming the stature, value and meaning of Ho Chi Minh's philosophical ideology for the development of Vietnamese philosophical ideology and Ho Chi Minh's contribution to the development of world philosophy are urgent issues in Vietnam's education today.

\section{Content}

\subsection{Theoretical origin of Ho Chi Minh philosophy}

Philosophical ideology and cultural traditions of the Vietnamese people

Over the past few thousand years of struggle to build and protect the country, the people of Vietnam with their sweats, efforts and blood have written the glorious history of a heroic nation. In this valuable inheritance, it exudes deep philosophical thoughts, becomes a philosophy of humanity, pride and one of the leading factors in the cultural and spiritual values of the Vietnamese people. Thus, when discussing the traditional philosophical ideology of the Vietnamese people, it means discussing the worldview, outlook on life and the most general methodology of the Vietnamese people as creators of history, which are used by the forebears in the struggle for survival, national construction and protection, handed down to the next generations of Vietnamese descendants. Without a worldview, outlook on life and philosophical methodology, the Vietnamese people are not able to exist and develop, not able to form and affirm the identity of Vietnamese culture with sustainable values, not to be eroded and faded before the "assimilation" of the Vietnamese with the Chinese of foreign enemies, turning Vietnam into a district of the reactionary forces in the North (Duong, 2001, p. 43-45).

From the childhood, Ho Chi Minh was influenced by his grandfather, his father and his Confucianism teachers in Nghe An on the independent, self-control, creative, and clear thinking style of the nation, taught about the history of patriotic tradition and tenacity of the people, and trained his patriotic spirit, love for people, hatred of injustice, brutality of the enemy. As an insider, Ho Chi Minh deeply felt the suffering of the people, the 
hard life in the homeland, the neighborhood; always felt great anguish at country losing its independence of the Vietnamese people when foreign enemies aggressed, etc. This practice urged Ho Chi Minh to overcome all difficulties and hardships; nurture the will, consolidate the faith, foster patriotic spirit, love for the people of Ho Chi Minh.

In his youth, Ho Chi Minh passed all prejudices and ideas of his peers, had a new perspective on the times, the world, the heart of the people, the fate of the country and the sense of responsibility of a patriotic citizen. The practical life helped Ho Chi Minh to soon form independent philosophical ideologies with new and sharp thinking, based on the critical, inheritance and selective acceptance of traditional philosophical ideologies of Vietnamese people, the quintessence of Confucianism, Buddhism, Taoism and many philosophical opinions and ideologies of Eastern and Western philosophical schools. Through this, Ho Chi Minh developed his philosophical thinking, raised to a higher level with new content, form, and new thinking style that was more suitable.

From human philosophy on the origin of race, ancestry; about an independent sovereign state; the unity creating the power of community, knowing to get the small to win the big, firm in objectives, flexible in strategies and tactics; the promotion of the unified heaven-human thought; the humanitarianism and the power of "remove mountains" of the people, Ho Chi Minh has deeply analyzed and clarified the close relationship between people and their families, their nation, their homeland and country, the nature and their desire to realize a life of peace, prosperity, freedom, happiness for all, toward the liberation of the nation and the liberation of humanity from all oppression, injustice, poverty and discrimination. This was generalized into the famous saying: "Nothing is more precious than independence and freedom" and many other sayings bearing deep thinking of a sage of the East, as well as the rhetorical, rational, and modern quintessence of Western philosophy; an effective cognitive tool to explain and improve the world.

Traditional Vietnamese philosophical ideology is an invaluable asset inherited, supplemented, and elevated to a new height by Ho Chi Minh. It expressed profoundly the crystallization between Vietnamese patriotism and the truth of the times: peace, independence, freedom, equality, and charity. The strength of the patriotic tradition, for the happiness of the people prompted Ho Chi Minh to leave to find a way to save the country in the name of Nguyen Tat Thanh. It was the force of ideology, the extremely strong emotions that govern the thinking, attitude, action and style of Ho Chi Minh. Although living in the foreign lands, meeting many difficulties, challenges, even dangerous life-threatening, Nguyen Ai Quoc - Ho Chi Minh still kept the spirit and will to save the country, always encouraged himself and compatriots, reminded people not to be far from the goal and ideal of national liberation. Starting from patriotism, Ho Chi Minh had received the quintessence of Western culture, the scientific and revolutionary values of Marxism-Leninism. Since then, he gradually raised the patriotism of Vietnam to a new height, linked the nation with the times, attached the true patriotism of the Vietnamese people to the international humanism, combined the national liberation with the human liberation and social liberation; abolished all oppression, exploitation, injustice, slavery, and domination (Duong, 2011, pp. 215).

Clearly, the philosophical ideology and cultural tradition of the Vietnamese people were the root, the endogenous element that was accumulated and permeated in a natural way, creating the uniqueness in philosophical thinking, helping Ho Chi Minh inherit and "re-process" all the values of philosophical quintessence and human culture into his own philosophical ideology and viewpoint, the cultural identity of Vietnam and East Asia. The philosophical ideology of Ho Chi Minh on national liberation, the liberation of the people of Vietnam and the oppressed peoples, etc. that brought people a prosperous and happy life originated from the patriotic tradition of Vietnamese people, especially the patriotism, the spirit of humanity, the tolerance of the Vietnamese people. This was one of the objective premises, which is especially important to create and illuminate the philosophical ideology of Ho Chi Minh and the style of Ho Chi Minh.

\section{Quintessence of Eastern and Western philosophies and cultures}

On quintessence of Eastern philosophy and culture. In addition to philosophical ideology, traditional Vietnamese culture, the formation of philosophical ideology of Ho Chi Minh was strongly influenced by Eastern philosophy, especially the influence of Confucianism, the Buddhism, and Taoism. At the same time, Ho Chi Minh absorbed and inherited the critical and selective philosophical ideology, the ideology of democracy and humanism of the cultures of the Renaissance, Enlightenment, of the French bourgeois revolution and Western culture to enrich the intellectual property and bravery of the nation of Vietnam.

The first education that Ho Chi Minh influenced and accepted was Confucianism. From childhood, Ho Chi Minh learned Chinese, received the philosophy of politics - social affairs and morality of - Confucius - Mencius through the classic books of Confucianism: "Four Books and Five Classics", lived in the style of a typical family of Confucianism, Ho Chi Minh for many years had lived in the Imperial city of Hue (Central of Viet Nam), which was the home of many Confucianism-devoted feudal kings, lords of Nguyen Dynasty, had contacted with many patriotic Confucian scholars when they talked with his beloved father. The knowledge that Ho Chi Minh absorbed was deep into his memory, leaving so deep impressions on ideology and sentiment that after many 
years of finding a way to save the country, although Ho Chi Minh was busy, he could still write poetry in Chinese (Prison Diary). It was not strange that in his writings and speeches, Ho Chi Minh often inherited and used Confucian philosophical ideology more than other Eastern philosophical schools (Viet, 2002, pp. 67 - 71 ). Some terms, concepts and categories of Confucian philosophy were inherited and used by Ho Chi Minh to express his ideas after they had been modified, supplemented with new contents and forms.

While absorbing and using Confucianism philosophical ideology, Ho Chi Minh criticized and rejected the idealistic elements of this doctrine. When inheriting and applying the "righteousness" of Confucianism, Ho Chi Minh eliminated the idealistic element of "heaven's will", restored the equality in the relationship among human; and considered that both President and farmer are all human beings. As human beings, everyone had the same right to live in freedom and equality. If done well, he or she will become the hero, the "saint" of today, and be very respected and proud.

Developing the philosophy of "being loyal to the king", "being filial to the parents", Ho Chi Minh said that each person should be not only filial to the parents but also loyal to the country and filial to the people. Criticizing the views of Confucianism when defying manual labor, scorning women, referring the people as "minor", Ho Chi Minh dismissed this "conservative" view and asserted: it must struggle for a fair, equal, democratic society, respect for labor, including both intellectual and manual labors, respect for women, equal rights for men and women, etc., Ho Chi Minh pointed out that women are a half of society and need to be respected.

The positive side of the Confucianism moral philosophy was concerned by Ho Chi Minh and was used to build new morality. It was the spirit of "benevolence and righteousness", the way of "self-development", the desire to learn, the humble virtue, "moderate", the "reasonable" human behavior. Accepting the "benevolence" factor of Confucius, Ho Chi Minh taught: "Do not make him what you do not want him to do for you" (Hồ Chí Minh toàn tập, 2011a, pp. 401). Since then, Ho Chi Minh raised the motto: "One for all and all for one". The criteria: diligence, thrift, integrity, justice, independence, self-criticism and criticism, intelligence, bravery, etc. that Ho Chi Minh concluded, generalized and raised were basically close to philosophical opinions of Confucius, but the only difference is that in Confucianism, the above criteria were "natural", while in Ho Chi Minh's ideology, they are due to the human training and self-development and due to their education and training to improve.

Clearly, Ho Chi Minh inherited, absorbed and applied the critical, selective much deep philosophical quintessence of Confucianism, like Karl Marx and Friedrich Engels absorbed idealism dialectics of Hegel and restated that dialectic on the basis of dialectical materialism.

Apart from Confucian philosophy and ethics, Ho Chi Minh also absorbed the philosophy of Buddhism. Developing the Buddha's philosophy of human supremacy role in the universe, Ho Chi Minh asserted that human power was the power of the national great unity block. He saw that the philosophical meaning and human virtue of "compassion, equality, charity" that the Buddha recited was to free people from suffering and brought a peaceful life for everyone. Ho Chi Minh harmonized the tolerant ideology of the Vietnamese people with the altruistic thought "to requite evil with good" of the Buddha. He advised compatriots: Do not requite and revenge. For the wrong and lost people, our compatriots need to use the generosity policy. Take the right to advise them. In order to educate revolutionary morality, to criticize the ideology of greed for power, the "An old fox not easily snared" position consolidation of some people with position and power, which are reduced their personality, Ho Chi Minh applied the humanity philosophy of "non-self", "impermanence" of Buddhism. It came from the obvious truth: "People are born, everyone grows up, grows old, and dies," the age of talent development and dedication was in a certain period. Therefore, it was necessary to find, select the people with the virtue, talent to undertake the national important works; people with meritorious services shall be rewarded, sick people with reduced health should be rested. Ho Chi Minh said that every people, especially those who were wrong, lost their way could become good people, progress if they recognized their defects, actively cultivated, trained, and fixed their defects.

Thus, Buddhism philosophy contributed to the formation of Ho Chi Minh's deep humanity philosophical thinking.

In Ho Chi Minh's writings, there are some philosophical ideology of Mohism and Taoism that Ho Chi Minh inherited, and applied to the moral and personality improvement of the patriotic citizens in the modern times. Significantly, in Mohism's philosophical ideology on "equally fraternal to everyone", Ho Chi Minh eliminated the idealistic factor, the classlessness of this theory, absorbed the spirit of loving all people, whatever was good for people, shall be dedicated, try to do the best, not be afraid of hardship, and promote humanity. From here, Ho Chi Minh stated: All cadres from the government to the villages "are the public servants of the people ... whatever benefits the people, do as much as possible. Whatever harm the people, avoid as much as possible. The cadres of the people must always tell themselves: Be worthy of being the leader, the true servant of the people. In all his life, Ho Chi Minh always thought and acted according to the motto of "for people, for country".

As a school of philosophy "existence", was introduced into Vietnam early, philosophical ideology of 
Taoism had a dialectical materialist element, but also had many limitations. Ho Chi Minh had refined and absorbed some progressive philosophical ideologies of Taoism, built a new philosophy on the scientific dialectics materialism to apply to the life. It was the ideology that is close to nature, harmony in nature, simple life, and serene soul, not the demand for reputation or power. Ho Chi Minh confided: "I just want to build a small house, in a place with green mountains and water, to go fishing, plant flowers, daily go to pick firewood with the elders, play with shepherds, do not involve the fame" (Hồ Chí Minh toàn tập, 2011a, pp. 187). This ideology was also reflected in the poetry of Ho Chi Minh. It was the deep love of nature, the closeness to the grass, beautiful and poetry scenery with birds singing, flowers blooming, with star moon, forest mountains, rivers and streams of Vietnam, etc. Although he is the President of a country, the life of Ho Chi Minh was simple: Some kaki clothes, rubber sandals, a small stilt house surrounded by a green forest. Despite thousands of works, Ho Chi Minh still spent time growing vegetables, farming fishes, and taking care of the garden, etc. The dialectical ideology of Taoism philosophy was also inherited and applied by Ho Chi Minh, especially the ideology of opposition transformation. The poems "Learn Chess", "Forest Scene in Viet Bac", "The Clouds broke ..." expressed this ideology. Clearly, the philosophy of Ho Chi Minh was strongly influenced by Confucian, Buddhist, and Taoist philosophy. Ho Chi Minh inherited a critical, selective Eastern philosophical and cultural quintessence, directly the quintessence of Chinese and Indian philosophies to enrich his intellectual knowledge and this was the most important luggage to Ho Chi Minh when going to find the way to save the country, coming to Marxism-Leninism and acquiring the humanity philosophy of "freedom, equality, charity" and cultural quintessence of the West.

On quintessence of Western philosophy and culture. Ho Chi Minh said that the reason for the failure of the insurrections against the invaders of the predecessors was that they had not overcome the limitations of traditional ideas - feudal ideology system. According to Ho Chi Minh, if you want to find a way to save the country, you must research, study, and absorb new ideological value system, must come and learn the Western experiences. What was most attractive to Ho Chi Minh at that time was the ideology system of the Enlightenment and the victory of the French bourgeois revolution, especially the slogan of "freedom, equality, charity", which Ho Chi Minh learnt while studying in French - Vietnamese primary school and Quoc Hoc High School for the Gifted in Hue.

Western civilization with the achievements of science and technology had aroused the thinking of the patriotic youth, Nguyen Tat Thanh, many new things. But in the country, due to conditions, the research was limited. Ho Chi Minh decided to go to Western countries in order to see how the people of the West achieved independence, but was still powerful and developed. Ho Chi Minh City studied the ideologies of the French, German Enlightenment; saw the power, the secrets, hidden behind the slogan of freedom, equality, charity, etc. This valuable property helped Ho Chi Minh return to the country to help people liberate the nation, build a prosperous country. All people lived in peace, independence, freedom, prosperity and happiness (Duong, 2011, pp. 78).

With determination to find a way to save the country and liberate the nation, Ho Chi Minh had been traveling for nearly 10 years to many developed countries in the world: France, England, Portugal, Italy, America, etc. and to some colonies such as Algeria, Congo, Senegal, Tunisia, etc. Ho Chi Minh worked hard, did many jobs to earn a living, contacted many prominent political-socialists, read many books, documents, and pondered about many things about the Declaration of Independence 1776 of the United States and the Manifesto of human rights and civil rights of France in 1789. Reading and studying the ideas of the Enlightenment philosophers such as Rousseau, Diderot, Voltaire, Holbach, Montesquieu, etc., and the new achievements of modern industry to conclude the comments and reviews to find out the good quintessence that needs to be absorbed and the limitations that need to be overcome. At the same time, he actively participated in the revolutionary struggles of the worker class of Western countries and the revolutionary struggles against colonialism, and contacted with the patriotic Vietnamese people. He wrote articles and distributed leaflets to denounce the crimes of invaders in Indochina. In 1918, he sent to the Vienne Conference a claim of eight points, claimed the recognition of the rights of freedom, democracy and equality of the Vietnamese nation. Later, the claim was published in the French Humanitarianism newspaper. After finding out, Ho Chi Minh was dissatisfied with the French Enlightenment philosophy and was not content with the way of the bourgeois revolution. The aspiration to find the way to save the country, save the people, and liberate the nation in Ho Chi Minh became more and more burning, urged Ho Chi Minh to Marxism-Leninism, carefully studied the Revolutions of France, Russia, America, etc.

From the above analysis, it can be said that Marxist - Leninist philosophy - the origin of the theory directly determining the new development step of the quality of Ho Chi Minh philosophical ideology. And so, the philosophy of Ho Chi Minh was the product of the combination of Vietnamese philosophical ideology, cultural tradition and Eastern and Western philosophical and cultural quintessence; had a close relationship with MarxistLeninist philosophy. Thanks to the accumulation and absorption of the quintessence of human knowledge, Ho Chi Minh had built his world view, outlook on life, scientific methodology, revolution to perceive and improve 
the world, etc.

Ho Chi Minh asserted that to save the country, liberate the nation, bring peace, prosperity, freedom and happiness to the people, there was no way except for doing a social revolution to flip the yoke of the old and decay regime; build the real state of the people, by the people and for the people. This was a basic turning point in the search for a way to save the country and the development of Ho Chi Minh's philosophical ideology. In which, the worldview of scientific materialist and revolution with the system of principles, rules, and philosophical categories was successfully applied by Ho Chi Minh, becoming the core, and playing a pivotal role in the philosophical ideology and practical activities of Ho Chi Minh.

Ho Chi Minh said that the most quintessence and the most outstanding thing which is the living soul of human philosophy is the materialism dialectics. Therefore, Ho Chi Minh required us to learn foreign experiences, of which the core was to master the "French dialectical spirit". Thus, we can use "firming objectives, flexible in strategies and tactics" flexibly and effectively. Summing up the experience of the Vietnamese revolution, Ho Chi Minh pointed out: We win because of many factors, but it should be emphasized that, ... we win those by firstly using the unmistakable weapon, that is the dialectical materialism and the quintessence of human intelligence.

These are the most authentic proofs that assert the objective necessity of the formation and development of philosophical ideology of Ho Chi Minh and Ho Chi Minh is a true philosopher of the Vietnamese nation.

\subsection{Practical foundation of formation of Ho Chi Minh's Philosophical ideology.}

Together with the theoretical origin, practical activities of Ho Chi Minh played an important role in the formation and development of philosophical ideology of Ho Chi Minh.

In his youth, Ho Chi Minh directly witnessed the pain of living in a divided and dominated country; the humiliation of slavery that was caused by crimes of colonialists and feudalists to his compatriots. When he grew up, he continued to witness the wars of the brave Vietnamese people against the invaders, the failure of his father's generation in the resistance movements made him extremely sorrowful. That was the reason why he decided to find a way to save the country and save the people. Ho Chi Minh experienced the rough life in not only his hometown but also in many other places in the Northern, Southern and Central Vietnam; therefore, he deeply understood the brutal exploitation of the French colonialists, corruption of the raffish Nguyen Dynasty and the consecutive failure of the anti-invasion insurrections at that time. The reality of life draw inspiration for him to constantly study, accumulate more knowledge, carefully select and receive progressive ideologies. Besides, he took it as the motivation to overcome any difficulty or challenge. Thanks to the obtained experience and the new, diversified and incisive knowledge, Ho Chi Minh clearly realized that who would become a friend, who was the enemy, what was wrong and what was right. Although Ho Chi Minh admired the patriotic fellows who found the ways to freedom, he disagreed to go on that ways. Ho Chi Minh was decisive to find new ways to save the country, save the people; which is going to France and the Western countries to achieve that goal. It was his wise decision that provided a new premise for exploring the path to national liberation in Vietnam (Duong, 2001, pp. 144).

In many years living in foreign countries, going to many places and continents including the Europe, Asia, America and Africa, He had worked as a vice-cook, a snow cleaner, a photographer, a journalist or an international communist cadre, and many other positions based on the different situations and conditions. It was definitely a rough time. In whatever job he did, Ho Chi Minh always tried to get over these challenges, enthusiastically participated in general struggle movement of mankind against oppression, exploitation and injustice; and tried to find solutions for issues related to the struggle for national liberation in Vietnam. In England, Ho Chi Minh actively participated in outdoor public speaking with politicians, philosophers and etc., supported the patriotic struggle of Algerian people. In America, he joined in meetings with black people in Haslam Street. In France, he contacted to Vietnamese patriots, enthusiastically took part in political activities, wrote articles and books, denounced the crimes of the invaders in Indochina, joined in Congress of Tours of French Socialist Party, voted for the International III and became the founder of Communist Party of France. Thereby, Ho Chi Minh studied, reviewed the life, aspirations and militant activities of the different peoples, studied ways of social organization and state management in the economic - political - communal regimes. Especially in years when Ho Chi Minh lived, worked, studied and researched in the Soviet Union, he gave insightful comments through the comparison between the Soviet Union and capitalist society in the America, England and France, gradually found the rules, then generalized his perception into theory. Ho Chi Minh applied that theory in the real situation of Vietnam at that time. Later, as a leader of the Vietnamese people, together with the Vietnamese people, he achieved the success of the August Revolution, then, the Democratic Republic of Vietnam was established. Ho Chi Minh continued to lead the Vietnamese people to fight against the invaders. The rich and varied practices contributed to Ho Chi Minh's living experience and they were considered the basis for Ho Chi Minh to continuously supplement, develop his ideas on a series of very basic issues of revolutionary theory. It was the dialectic combination of awareness and action, words and deeds, and, theory and practice. It was certain that revolutionary situation at that time created the philosophical ideology of Ho Chi Minh - an 
ideology of depth, uniqueness, independence, autonomy and creativity (Duong, 2001, pp. 145).

To sum up, practical revolutionary activity is an origin, a basis for the formation and development of Ho Chi Minh's philosophical ideology, a factor to make Ho Chi Minh's philosophical ideology a practical one, guide the way for the Vietnamese people to fight for national liberation, build a prosperous and happy country.

\subsection{Positive qualities and personality of Ho Chi Minh}

Dialectical impacts among objective conditions and subjective factors of Ho Chi Minh created a necessary premise system for the formation and development of Ho Chi Minh's philosophical ideology. If there is no systematical and basic study on the function of subjective factors of Ho Chi Minh, it will be difficult to apply science knowledge for explaining the basis of Ho Chi Minh philosophical ideology which was so deep and unique.

When he was a child, Ho Chi Minh owned a hug asset which was the love and intellect from his beloved father and family members. Growing up, he studied at Vietnam - France Primary School and the famous Quoc Hoc - Hue High School for the Gifted. Hence, Ho Chi Minh soon had a chance to approach the quintessential philosophy, national and Oriental culture, Western civilization with many achievements of ideology and modern science and technology. Besides, Ho Chi Minh was a person who had positive qualities, excellent capacity, extreme intelligence, sharp thinking and acumen towards new things; furthermore, he was always eager to learn new aspects. All these things made Ho Chi Minh become a person of extensive knowledge and erudite brainpower, whose conclusion and comments presented clearly his independent, free and creative thinking

Ho Chi Minh's life is a beautiful example of perseverance, difficulty and hardship endurance, strong and indomitable willpower as well as idiosyncrasy, steadfast and steady bravery to obtain the determined targets and ideal. Ho Chi Minh devoted his whole life for the country and the people: His meaningful life is to live and save the country, get the national liberation, prevent Vietnamese people from torment, help them escape from oppression, exploitation, injustice and corruption. Ho Chi Minh believed that it was the most sacred and humane ideal of life of a human being. He said: "Freedom for my compatriots, independence for my Nation, that is all I want and all I understand". Throughout his life, Ho Chi Minh "had only an appetency, a biggest appetency, which is to make the country completely independent, make the Vietnamese people completely free, give all compatriots enough foods, clothes and give them a chance to go to school." Ho Chi Minh was one of the most elite Vietnamese patriots and the most significant example for the Vietnamese people.

Being a model of revolutionary virtue, a refined and pure lifestyle, and a moral exemplar: being hardworking, economizing, having integrity and not corrupting. Ho Chi Minh lived and worked in a very simply, sincere, modest way, closely to the people; had a strong belief in the people and a great ability to convert the people.

These noble qualities and personality of Ho Chi Minh were promoted during his life for the country and the people. As a result, Ho Chi Minh passed the contemporary patriots to find the right target, revolutionary ideal and the way to the goal, then realized that ideal. That was also the factor helping Ho Chi Minh overcame all difficulties, challenges and cruel situation in which his life and political mission were threatened. Then, He got over it, stood firm, made right lucid decisions, turned his ideology into reality, always steadily steered to raise the boat of revolution in Vietnam up, go to the shore of glory and happiness (Nghia, 2017, pp. 195-198).

It was concluded that subjective factors of Ho Chi Minh played an important role and was an essential condition for the formation of Ho Chi Minh's philosophical ideology. It was the dialectical unity between tradition and modernity, positive qualities and abilities, talent and virtues inside Ho Chi Minh. Ho Chi Minh's philosophical ideology was not only the inheritance and creative application of the ideological elite Western philosophy and culture but also new development and enrichment for philosophical ideology of Vietnam by the addition of ideological elite Western philosophy and culture, especially issues related to historical materialism. It was a "secret" explaining why and how Ho Chi Minh became a philosopher, why He could lead the Vietnamese revolution successfully in achieving the goal of national liberation, building a prosperous country, making positive contributions to world peace.

\section{Outcomes}

\section{Quintessence of Ho Chi Minh's philosophical ideology}

In many his sayings or writings, Ho Chi Minh barely used philosophical language and did not acknowledge himself as a philosopher, but in his mind was always consistent with a world view, an outlook on life and a method of philosophical thinking.

The nature of worldview and outlook on life in Ho Chi Minh's philosophy was dialectical materialism and historical materialism. Ho Chi Minh protected, developed and raised the philosophical ideology of the Vietnamese people on the basis of Eastern and Western philosophy; collected all the quintessential wisdom of mankind. Unlike his predecessors, Ho Chi Minh did not leave a philosophical work such as: German Ideology, the Thesis of Feuerbach, the Dialectics of Nature, the Philosophical Writings, etc. as the founders of Marxism 
and Leninism. It was because Ho Chi Minh lived and operated the revolutionary in the age that there were existing scientific theory and revolutionary to enlighten and guide him. His mission was to save the country, save the people, liberate the nation from oppression, exploitation and injustice; bring peace, freedom, prosperity and happiness for the people. It was this mission that attracted all Ho Chi Minh's spirit and strength, made Ho Chi Minh closer to the people, turned all the essence and depth of philosophy into simple, detailed, defined and practical things so that the Vietnamese people would be easy to understand and easy to follow. Obviously, Ho Chi Minh must possess a proficient philosophical level so that he could transform theoretical philosophy into the philosophy of life. Thereby, he gave the people a world view of dialectical materialism, which would help them to exactly recognize, consider and evaluate the situation; then, work out practical and effective guidelines, undertakings and policies; at the same time, not fall into oscillation, not make delusional, subjective and idealism mistakes as well as dogma and review; in spite of the fact that Ho Chi Minh used little philosophical terms in his both sayings and writings. (Giap, 1997, pp. 63 - 72).

Studying the theoretical heritage of Ho Chi Minh, we may realize deep philosophical ideology. Ho Chi Minh based on the fundamental problem of philosophy to solve the relationship between the improvement of material life and spiritual life, the development of production and the strengthening of the political system, the economic growth and the development of education, culture and many other relationships such as the connection between building the country and fighting against invaders, defending our Nation; combined the strength of the nation with that of the times, got combination of the resistance war and the national anthem, expressed the distinctive humanistic values that were full of dialectical morals. His philosophical ideology was the harmony among the patriotism of Vietnam, the quintessence of the Western culture and philosophy, with the clever combination between the "impermanence of things" Eastern in philosophy and dialectical materialism of Western philosophy.

The world view of Ho Chi Minh's philosophy was a scientific world view. The direction of Ho Chi Minh's philosophy ideology was to focus on social and humanitarian issues with the noble political purpose of "saving the country, saving the people and liberating the people". Ho Chi Minh paid special attention to the construction of social - political theories and moral in order to solve practical problems rather than the form of epistemological and logical philosophy as philosophers usually did.

Ho Chi Minh's philosophical ideology was developed on a firm foundation of the dialectical materialist stance, historical materialism, and applied into the social reality of Vietnam and liberating people from oppression, exploitation and injustice together with bringing about a peaceful life, freedom and happiness for the compatriots was considered the key point for the purpose that he was apporaching and reaching. In fact, this was Ho Chi Minh's great contribution to the protection and development of historical materialism.

The world view, outlook in life and the method of Ho Chi Minh's philosophy contained the nature of scientific and revolutionary, based on the world view of dialectical materialism, historical materialism and atheism. Throughout Ho Chi Minh's philosophical ideology was the contents of devoting his whole life for the nation, the people and struggle for national liberation, social liberation and human liberation.

Confirming and promoting the role of theories, Ho Chi Minh had never neglected or reduced the importance of experience. Ho Chi Minh affirmed that the unity between theory and practice would be a basic principle directing actions. Ho Chi Minh used the concept of not only reality but also practice and He even used these concepts for many times. For Ho Chi Minh, the reality was not opposed to practice but its content is larger then practice's one. On dicussing the unity between theory and practice as a basic principle of dialectical materialism, Ho Chi Minh often used the concept of practice; however, he used the concept of reality instead of practice to talk about the application of theory into practice and the connection between two elements. Nowsaday, in our daily life, we normally understand and use the concept of reality as same as that of practice (see Vietnamese Dictionary 1991).

In the philosophical world view of Ho Chi Minh, the factor of human beings was extremely vital. To access and solve human-beings-related problems, Ho Chi Minh mentioned to human in reality, labor and "My compatriots". Ho Chi Minh's noble humanism is manifested in the love of human beings, respect and belief in the people, consideration of revolutionary as a life-work of the people, by the people, for the people.

\section{Characteristics of Ho Chi Minh's philosophical ideology}

Based on the above opinions, it is referred that Ho Chi Minh's philosophical ideology consists of following characteristics:

Firstly, Ho Chi Minh's philosophical ideology is a clever combination between science and revolution, opinions and method of cognition and action. This combination is both the characteristics of Ho Chi Minh's philosophical ideology and guiding principle for Ho Chi Minh's awareness and action. It also expresses the unity in his philosophical ideology.

Secondly, Ho Chi Minh's philosophical ideology is an independent, active, creative and unified one between theory and practice, ideology and action, word and works completing the cycle of movement: from the vivid 
visions to abstract thinking, from abstract thinking to practice.

Thirdly, Ho Chi Minh's philosophical ideology is presented by simple, pure and universal language, which helps others easily understand and helps itself easily penetrate the masses. This seems to be a unique feature of Ho Chi Minh's philosophical thinking.

Finally, basic methodology across Ho Chi Minh's philosophical ideology is derived from objective reality and respect for objective rules: catch accurate practical perspective and apply appropriately the rules on unity of theory and practice; solve comprehensively any problem; emphasize the key points and get the efficiency as the purpose; review any matter in its development; implement "flexible in strategies and tactics"; resolve on the ground of human beings, for human beings and all for the people's happiness (Nghia, 2017, pp. 293-295).

Ho Chi Minh's Methodology is the methodology of dialectical materialism and historical materialism. It is purely a dialectics of Ho Chi Minh, is the precept for review and scientific action that was generated through his acquisition, inheritance, creative application and supplementation, the development of Marxist dialectical materialism, in the combination with inheriting the tradition of national ideology, Eastern philosophical ideology and practical the Vietnamese-revolution-based solutions.

\section{Conclusion}

Ho Chi Minh's philosophical ideology is a system of dialectical materialism perspectives and conception related to the Revolutionary Pathways of Vietnam, promoting the revolution of national liberation and contributing to the construction of People's democracy, a peaceful, independent, unified, democratic and prosperous Vietnam and the construction as well as protection for the world peace.

Ho Chi Minh's philosophical ideology is a foundation for the world view, methodology for revolution. Furthermore, it is the spirit, the winning flag of revolution in Vietnam over the past 8 decades and in the following years.

Ho Chi Minh's ideology in which its core is the world view and methodology of dialectical materialism is always the foundation of ideology, functioning as the lodestar for any action of the Vietnamese. A study of Ho Chi Minh's ideology, especially his philosophical ideology, is a scienctific work. It is a great importance in developing the world view and dialectical method for the work-people in the cause of innovation, industrialization and modernization of the country for the purpose of: wealthy people, strong country, just and civilized society./.

\section{REFERENCES}

Duong, N. B. (2001), Bước đầu lựa chọn cách tiếp cận tư tưởng triết học Hồ Chí Minh [Initial selection to approach Ho Chi Minh's philosophical ideology], Journal of Military Political Theory and Education, No. 3

Duong, N. B. (2011): Học thuyết Mác - Lênin, tư tương Hồ Chí Minh, nhũng giá trị vĩnh hằng [Marxist-Leninist doctrine and Ho Chi Minh's ideology - the eternal values]. Hanoi: National Political Publishing House.

Giap, V. N. (1997). Tu tương Hồ Chí Minh và con đưòng cách mạng Việt Nam [Ho Chi Minh's Ideology and Revolutionary Pathways of Vietnam]. Hanoi: National Political Publishing House.

Hồ Chí Minh toàn tập [Collection of Ho Chi Minh]. (2011a). Vol. 4. Hanoi: National Political Publishing House.

Hồ Chí Minh toàn tâp [Collection of Ho Chi Minh]. (2011b). Vol. 4. Hanoi: National Political Publishing House.

Nghia, L. H. (1996). Bước đầu tìm hiểu tư tưởng triết học Hồ Chí Minh [First steps of exploring Ho Chi Minh's philosophical ideology]", Philosophy Journal, No. 2 (90).

Nghia, L. H. (2000). Tu tuớng triết học Hồ Chí Minh [Ho Chi Minh's philosophical ideology]. Hanoi: Labour Publishing House.

Nghia, L. H. (2017): Chủ nghĩa Mác - Lênin, tu tuoơng Hồ Chí Minh với công cuốc đổi mói của Việt Nam [Marxism - Leninism, Ho Chi Minh's ideology with the Renonvation of Vietnam]. Hanoi: National Political Publishing House.

Rua, T. H., Bao, H. C. (2017). Nghiên cúu chủ thuyết phát triển của Việt Nam trong thời đại Hồ Chí Minh [A study of the developmental doctrine of Vietnam in the Ho Chi Minh's era]. Hanoi: CK Book.

Viet, H. K. (2002): Góp phần tìm hiểu đặc sắc tu duy triết học Hồ Chí Minh [A contribution to exploration of Ho Chi Minh’s philosophical ideology]. Hanoi: National Political Publishing House.

Table 1. Type your title here.

Figure 1. Type your title here. Obtain permission and include the acknowledgement required by the copyright holder if a figure is being reproduced from another source. 